\title{
Performance of Anthill Soil Replaced Concrete in Sulfate Solutions
}

\author{
John Kamau, Ash Ahmed, Paul Hirst and Joseph Kangwa
}

\begin{abstract}
Durability of concrete is defined as its ability to resist any form of deterioration, allowing it to retain its original form and quality after it has been exposed to the environment of its intended use. Sulfate attack causes concrete to lose its compressive strength through the decomposition of the products of hydration of cement. Pozzolanic reactions from Supplementary Cementitious Materials (SCMs) help in resisting the sodium sulfate $\left(\mathrm{Na}_{2} \mathrm{SO}_{4}\right)$ attack. This work investigated the potential use of Anthill Soil (AHS) to improve the performance of concrete in sulfate aggressive environments. An AHS replacement of $30 \%$ (per cent) by the weight of cement was used to make concrete test bars and cubes. The $0 \%$ replacement also referred to as the control was used as the point of reference from which all performances were measured. The specimens were immersed in $5 \% \mathrm{Na}_{2} \mathrm{SO}_{4}$, $5 \%$ magnesium sulfate $\left(\mathrm{MgSO}_{4}\right)$, and $5 \%$ mixed solution of $\mathrm{Na}_{2} \mathrm{SO}_{4}$ and $\mathrm{MgSO}_{4}$. Elongation measurements were taken over a period of 9 months, whereas compressive strength tests, which were used to work out the Strength Deterioration Factors (SDFs) and visual observations for surface deterioration were carried out at 9 months. From the results, AHS specimens that were immersed in the $\mathrm{Na}_{2} \mathrm{SO}_{4}, \mathrm{MgSO}_{4}$ and mixed $\mathrm{Na}_{2} \mathrm{SO}_{4}$ and $\mathrm{MgSO}_{4}$ solutions performed poorly in elongation compared with the control specimens, but had lower SDFs in the $\mathrm{Na}_{2} \mathrm{SO}_{4}$ and mixed solutions of $\mathrm{Na}_{2} \mathrm{SO}_{4}$ and $\mathrm{MgSO}_{4}$. The surface deterioration of AHS specimens in the $\mathrm{MgSO}_{4}$ solution was worse than that of the control specimens but was similar to that of the control in the mixed sulfate solution of $\mathrm{Na}_{2} \mathrm{SO}_{4}$ and $\mathrm{MgSO}_{4}$. The SDF results highlight the potential of using AHS with an advantage in $\mathrm{Na}_{2} \mathrm{SO}_{4}$ and mixed $\mathrm{Na}_{2} \mathrm{SO}_{4}$ and $\mathrm{MgSO}_{4}$ environments.
\end{abstract}

Index Terms-Anthill Soil; Sulfate Attack; Sulfate Resistance; Sulfate Aggressive Environments.

\section{INTRODUCTION}

Durability of concrete is defined as its ability to resist any form of deterioration, allowing it to retain its original form and quality after exposure to the environment of its intended use [1].

Deterioration can be from external chemical attack, or internal chemical reactions from the constituents of concrete [1]. Sulfate attack is a durability concern that causes concrete to lose its compressive strength, with severity

Published on May 24, 2017.

J. Kamau is with the Civil Engineering Group. Leeds Beckett University, Leeds, England, UK (email: John.kamau@yahoo.com)

A. Ahmed is with the Civil Engineering Group. Leeds Beckett University, Leeds, UK (email: A.R.Ahmed@leedsbeckett.ac.uk)

P. Hirst is with the Civil Engineering Group. Leeds Beckett University, Leeds, England, UK (email: P.Hirst@leedsbeckett.ac.uk)

J. Kangwa was with the Civil Engineering Group. Leeds Beckett University, Leeds, England, UK. He is now with London South Bank University, London, England, UK (email: kangwaj2@1sbu.ac.uk) depending on the type of sulfate [2].

Sulfate attack brings about the decomposition of the products of hydration of cement, resulting in the formation of new compounds, which may be leached out if soluble or disruptive if insoluble [1].

The products of hydration that are susceptible to sulfate attack are calcium hydroxide $\left[\mathrm{Ca}(\mathrm{OH})_{2}\right]$ and Calcium Silicate Hydrates (C-S-H) [3], [4].

All commonly available water-soluble sulfates are deleterious to concrete, but the most severe effects are observed when the attack is associated with magnesium cations [2].

Higher sulfate concentrations in water are due to magnesium sulfate $\left(\mathrm{MgSO}_{4}\right)$, which is highly soluble in water at room temperature $\left(20^{\circ} \mathrm{C}\right)$ when compared to sodium sulfate $\left(\mathrm{Na}_{2} \mathrm{SO}_{4}\right)$ [2].

$\mathrm{Ca}(\mathrm{OH})_{2}$ in $\mathrm{Na}_{2} \mathrm{SO}_{4}$ environments reacts with sulfates to form calcium sulfate $\left[\mathrm{CaSO}_{4} .2\left(\mathrm{H}_{2} \mathrm{O}\right)\right]$, also known as gypsum, and/or with unhhydrated tri-calcium aluminate, also known as alite $\left(\mathrm{C}_{3} \mathrm{~A}\right)$ and alumina-bearing hydration products to form expansive ettringite [5]. A precipitation of gypsum and ettringite can generate stresses within the concrete, which if greater than the tensile strength of the concrete may result in strength loss, expansion, spalling and severe degradation [2]. As a result, $\mathrm{Na}_{2} \mathrm{SO}_{4}$ attack is manifested and evaluated through expansion [2].

$\mathrm{MgSO}_{4}$ attack, on the other hand is determined by the outwards diffusion of hydroxide ions to form brucite and inwards diffusion of sulfate ions to form gypsum [6]. This combined layer of gypsum and brucite retards the harmful effects of $\mathrm{MgSO}_{4}$ attack in the early ages, but it latter peels off at latter ages due to the formation of expansive ettingite and gypsum, which causes cracking on the surface of the brucite layer [2]. As a result, the decomposition of C-S-H gel to the non-cementitious Magnesium Silicate Hydrate (M-S-H) gel permits the easy diffusion of sulfate ions into the hardened cement matrix [4]. This alteration of C-S-H to $\mathrm{M}-\mathrm{S}-\mathrm{H}$ is probably the major process and final stage of $\mathrm{MgSO}_{4}$ attack, and it brings about the reduction in strength of concrete [2]. As a result, $\mathrm{MgSO}_{4}$ attack is manifested and evaluated through the loss of strength of concrete [2].

Following the attack of magnesium ions on C-S-H, a poor performance of Supplementary Cementitious Materials ( $\mathrm{SCMs}$ ) concrete in $\mathrm{MgSO}_{4}$ environments has been reported [2], [7].

Alongside the presence of $\mathrm{Ca}(\mathrm{OH})_{2}$, low sulfate resistance is also characterised by high contents of Sulfate $\left(\mathrm{SO}_{4}\right)$, iron oxide $\left(\mathrm{Fe}_{2} \mathrm{O}_{3}\right)$ and $\mathrm{C}_{3} \mathrm{~A}$, and low levels of silicon dioxide $\left(\mathrm{SiO}_{2}\right)$ [3]. A high molar ratio of sulfite $\left(\mathrm{SO}_{3}\right)$ to aluminium oxide $\left(\mathrm{Al}_{2} \mathrm{O}_{3}\right)$ increases the risk of the formation of monosulfate that otherwise results in expansive ettringite 
and gypsum on exposure to sulfate attack [2].

Pozzolanic reactions from SCMs such as Pulverised Fuel Ash (PFA), Ground Granulated Blast Furnace Slag (GGBS), Silica Fume (SF), Rice Husk Ash (RHA) and Corncob Ash (CCA) help in resisting the $\mathrm{Na}_{2} \mathrm{SO}_{4}$ attack as they refine pores, dilute $\mathrm{C}_{3} \mathrm{~A}$ and due to their low ratio of calcium to silica, remove $\mathrm{Ca}(\mathrm{OH})_{2}$ by converting it into the cementitious $\mathrm{C}-\mathrm{S}-\mathrm{H}$ gel, thereby reducing permeability and the quantities of gypsum formed [2,3].

Anthills, shown in Fig. 1 are made up of soil grains that are coated with sticky rapidly hardening secretions from the recta and mouths of ants, and are very cohesive [8]. Their suitability to be used as a SCM was investigated by "unpublished" [9]. Table I shows the chemical composition of AHS that was obtained by [9] from an X-ray diffraction. ASTM C618 [10] and [11] require that natural pozzolans should contain a combined sum of silicon dioxide $\left(\mathrm{SiO}_{2}\right)$, Aluminium oxide $\left(\mathrm{Al}_{2} \mathrm{O}_{3}\right)$, and Iron oxide $\left(\mathrm{Fe}_{2} \mathrm{O}_{3}\right)$ of at least $70 \%$ of the total mass and a LOI of between $5 \%$ and $10 \%$. From the results, AHS contained the required chemical composition to allow them to be characterised with natural pozzolans.

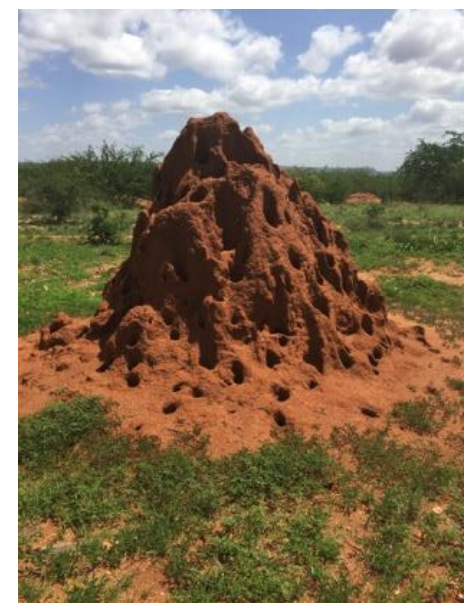

Fig. 1. Anthill soil in Tsavo National Park West (picture by authors)

Table II and Fig. 2 show the compressive strengths obtained by [9] from AHS-replaced specimens. From these results, AHS achieved compressive strengths that are among those listed by [12] as being durable and suitable for structural applications.

According to [13], the durability of concrete is directly proportional to its compressive strength, and from the findings of [9] it may be deducted that Anthill Soil (AHS) could poses a high durability after longer periods of curing, as it has been reported that the early strength of pozzolanic concrete is lower, but is higher at latter ages due to the consumption of $\mathrm{Ca}(\mathrm{OH})_{2}$ by the pozzolanic reaction to form further C-S-H, which is strength giving [2]. Pozzolanic concretes have therefore been reported to achieve strengths that are either close to or above those of $100 \%$ cement concretes [2].

TABLE I. Percentage Chemical Composition of AHS Used

\begin{tabular}{cc}
\hline \hline Chemical & Percentage Composition \\
\hline Silicon dioxide $\left(\mathrm{SiO}_{2}\right)$ & 51.9 \\
\hline Aluminium oxide $\left(\mathrm{Al}_{2} \mathrm{O}_{3}\right)$ & 23.4 \\
\hline Iron oxide $\left(\mathrm{Fe}_{2} \mathrm{O}_{3}\right)$ & 7.0 \\
\hline Calcium oxide $(\mathrm{CaO})$ & 1.6 \\
\hline
\end{tabular}

\begin{tabular}{cc} 
Magnesium oxide $(\mathrm{MgO})$ & 2.4 \\
\hline Sodium oxide $\left(\mathrm{Na}_{2} \mathrm{O}\right)$ & 0.4 \\
\hline Potassium oxide $\left(\mathrm{K}_{2} \mathrm{O}\right)$ & 1.9 \\
\hline Loss on ignition $(\mathrm{LOI})$ & 9.3 \\
\hline Sulphur trioxide $\left(\mathrm{SO}_{3}\right)$ & 0.1 \\
\hline \hline
\end{tabular}

TABLE II. COMPRESSIVE STRENGTH OF AHS SPECIMENS (N/MM2) BY KAMAU, ET AL. [9]

\begin{tabular}{ccccccccc}
\hline \multicolumn{1}{c}{$\begin{array}{l}\text { Curing } \\
\text { age } \\
\text { (days) }\end{array}$} & \multicolumn{7}{c}{ Compressive strength at percentage replacement $\left(\mathrm{N} / \mathrm{mm}^{2}\right)$} \\
\cline { 2 - 10 } & $0 \%$ & $5 \%$ & $7.50 \%$ & $10 \%$ & $15 \%$ & $20 \%$ & $25 \%$ & $30 \%$ \\
\hline 7 & 56.2 & 40.4 & 40.3 & 38.1 & 33.2 & 32.6 & 27.1 & 22.3 \\
\hline 28 & 61.6 & 50.8 & 53.4 & 46 & 43.4 & 38.7 & 34.6 & 28.8 \\
\hline 56 & 67.6 & 53.4 & 50.6 & 47.9 & 48.1 & 44.8 & 39.2 & 31.8 \\
\hline 91 & 71.3 & 59.3 & 63.1 & 55.6 & 54.1 & 49.1 & 44.4 & 37.8 \\
\hline \hline
\end{tabular}

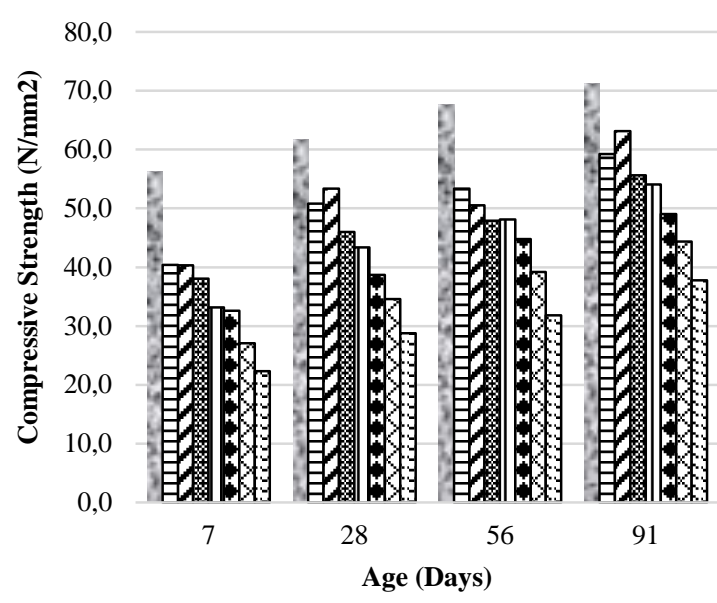

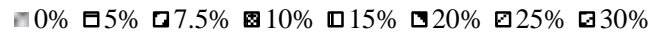

Fig. 2. Compressive strengths of AHS specimens $\left(\mathrm{N} / \mathrm{mm}^{2}\right)$ by [9]

Table III and Fig. 3 show the densities obtained by [9]. From these findings, the densities of AHS-replaced specimens remained below those of $100 \%$ cement specimens throughout all replacements and decreased with further replacement and curing age. This behaviour in density is a characteristic of SCMs due to their lower particle specific gravity and also the consumption of $\mathrm{Ca}(\mathrm{OH})_{2}$ with curing to form the less dense Calcium Silicate Hydrate (C-S-H) [2], [14].

TABLE III. DENSITIES OF AHS-REPLACED SPECIMENS OVER 91 DAYS OF CURING $\left(\mathrm{KG} / \mathrm{M}^{3}\right)$ [9]

\begin{tabular}{ccccccccc}
\hline \hline \multicolumn{7}{c}{ Densities of AHS specimens at percentage replacements $\left(\mathrm{kg} / \mathrm{m}^{3}\right)$} \\
\hline $\begin{array}{c}\text { Age } \\
\text { (days) }\end{array}$ & $0 \%$ & $5 \%$ & $7.5 \%$ & $10 \%$ & $15 \%$ & $20 \%$ & $25 \%$ & $30 \%$ \\
\hline 7 & 2350 & 2330 & 2329 & 2326 & 2325 & 2278 & 2274 & 2266 \\
\hline 28 & 2350 & 2320 & 2327 & 2325 & 2323 & 2271 & 2265 & 2259 \\
\hline 56 & 2356 & 2320 & 2326 & 2323 & 2316 & 2258 & 2247 & 2238 \\
\hline 91 & 2366 & 2318 & 2314 & 2312 & 2307 & 2250 & 2243 & 2202 \\
\hline \hline
\end{tabular}




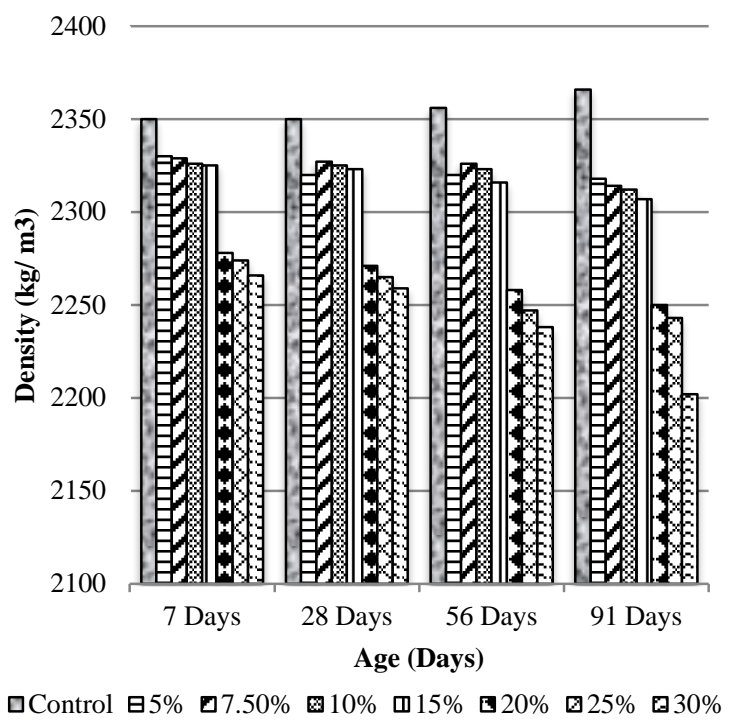

Fig. 3. Densities of AHS-replaced specimens against curing age $\left(\mathrm{kg} / \mathrm{m}^{3}\right)$ [9]

\section{RESEARCH SIGNIFICANCE}

There is generally a shortage of portable tap water for use in mixing concrete in the developing world [15]. Most people, especially from peri-urban settings will use any available water for this purpose, such as that obtained from boreholes, sewages and swamps [15]. Some of the water from these environments may be contaminated and can be a source of aggressive ions on concrete, which can result in a reduced service life of structures due to expansion, cracking, spalling and loss of compressive strength [15].

No work was found on the resistance of Anthill Soil (AHS) replaced concrete to sulfate attack. This work investigated the performance of AHS-replaced concrete in sulfate solutions.

\section{METHODS}

The sulfate elongation tests conformed to [16]. Cubic prismatic samples measuring $160 \mathrm{~mm}$ x $40 \mathrm{~mm}$ x $40 \mathrm{~mm}$ and cubes measuring $100 \mathrm{~mm} \times 100 \mathrm{~mm} \times 100 \mathrm{~mm}$ for sulfate elongation and strength deterioration tests respectively were prepared and cast with a 30\% AHS replaced concrete mix. The $0 \%$ replacement, also referred to as the control was used as the point of reference from which all performances were measured [1].

The moulds were covered with a plastic plate and placed in a sealed curing container to prevent evaporation. They were then placed in an oven for $23^{1 / 2}$ hours at $35^{\circ} \mathrm{C}$, after which they were removed from the container and demoulded. Two cubes were crushed to ensure that the concrete had achieved compressive strengths of 20.0 $\mathrm{N} / \mathrm{mm}^{2}$. The lengths of test specimens were taken before they were immersed in $5 \% \mathrm{Na}_{2} \mathrm{SO}_{4}, 5 \% \mathrm{MgSO}_{4}$, and $5 \%$ $\mathrm{Na}_{2} \mathrm{SO}_{4}$ and $\mathrm{MgSO}_{4}$ solutions at laboratory temperatures of $23^{\circ} \mathrm{C}$.

A pH of 6 to 8 was maintained on the sulfate solutions throughout the test period. Length changes were measured using veneer calipers at 1, 2, 3, 4, 8 weeks, and 4, 8, and 9 months, and worked out by using (1) to [16].

$$
\Delta \mathrm{L}=\frac{\mathrm{Lx}-\mathrm{Li}}{\mathrm{Lg}} \times 100
$$

Where;

$\Delta \mathrm{L}=$ percentage change in length at measuring age, $\mathrm{L}_{\mathrm{x}}=$ reading of specimen at measuring age, $\mathrm{L}_{\mathrm{i}}=$ reading of specimen at immersion, $\mathrm{L}_{\mathrm{g}}=160$ (nominal length between the innermost ends of the moulds used).

Strength deterioration was assessed using the Strength Deterioration Factors (SDFs), which were calculated by using (2) after [4].

$$
S D F=\frac{f_{c w^{\prime}}-f_{c S \prime}}{f_{c w^{\prime}}} X 100
$$

Where fcw' is the compressive strength of control specimen cubes and fcs' is the compressive strength of sulfate immersed specimen cubes.

To ensure repeatability, a total of three specimens were cast for each test and the average of elongation and SDF was reported [16]. Surface deterioration was observed at 9 months. The $\mathrm{C}_{3} \mathrm{~A}$ content of AHS was calculated by using (3), which was obtained from the Bogue calculation [17]

$$
\mathrm{C}_{3} \mathrm{~A}=2.6504 \mathrm{Al}_{2} \mathrm{O}_{3}-1.6920 \mathrm{Fe}_{2} \mathrm{O}_{3}
$$

\section{RESULTS AND DisCUSSIONS}

\section{A. Chemical analysis}

From the chemical analysis shown in Table I, AHS contained a low ratio of $\mathrm{CaO}$ to $\mathrm{SiO}_{2}$, which according to [2] removes $\mathrm{Ca}(\mathrm{OH})_{2}$, thereby improving sulfate resistance. Also, a high level of $\mathrm{SiO}_{2}$ and a low level of $\mathrm{Fe}_{2} \mathrm{O}_{3}$, and a low ratio of $\mathrm{SO}_{3}$ to $\mathrm{Al}_{2} \mathrm{O}_{3}$ contained in AHS were reported by [2] to be an indication of high sulfate resistance. $\mathrm{C}_{3} \mathrm{~A}$ in AHS was calculated by using (3).

\section{B. Elongation}

Tables IV, V and VI, and Figs. 4, 5, and 6 show the elongation of AHS specimens in the $\mathrm{Na}_{2} \mathrm{SO}_{4}, \mathrm{MgSO}_{4}$, and the mixed solutions of $\mathrm{Na}_{2} \mathrm{SO}_{4}$ and $\mathrm{MgSO}_{4}$ respectively. A standard deviation of 0.04 was calculated across the range of tests.

The elongations of AHS specimens were higher than those of the control specimens in the $\mathrm{Na}_{2} \mathrm{SO}_{4}$ solution. These results were not consistent with [4] who reported lower expansions in the $\mathrm{Na}_{2} \mathrm{SO}_{4}$ solution for SF replaced specimens, and attributed it to the pozzolanic reaction which helps in resisting sulfate attack through the refining of pores, dilution of $\mathrm{C}_{3} \mathrm{~A}$ and removal of $\mathrm{Ca}(\mathrm{OH})_{2}$ by converting it into the $\mathrm{C}-\mathrm{S}-\mathrm{H}$ gel, thereby reducing the quantities of gypsum formed [2].

Even though AHS contained a high level of $\mathrm{SiO}_{2}$ and a low level of $\mathrm{Fe}_{2} \mathrm{O}_{3}$, as well as a low molar ratio of $\mathrm{SO}_{3}$ to $\mathrm{Al}_{2} \mathrm{O}_{3}$, which were reported by [2] and [18] as being an indication of high sulfate resistance, its poor performance in the $\mathrm{Na}_{2} \mathrm{SO}_{4}$ solution could be attributed to the high contents of $\mathrm{Al}_{2} \mathrm{O}_{3}$ and $\mathrm{C}_{3} \mathrm{~A}$, which was calculated at $50.2 \%$. According to [19], the content of $\mathrm{Al}_{2} \mathrm{O}_{3}$ should not exceed $14 \%$, and if it does, $\mathrm{C}_{3} \mathrm{~A}$ should not be above $10 \%$ for good sulfate resistance.

Although according to [4] and [7] sulfate attack that is 
associated with $\mathrm{MgSO}_{4}$ is not characterised by expansion, elongation was recorded on specimens that were immersed in both the $\mathrm{MgSO}_{4}$ and the mixed solution of $\mathrm{Na}_{2} \mathrm{SO}_{4}$ and $\mathrm{MgSO}_{4}$, with AHS specimens showing higher expansions than those of the control specimens. Park, et al. [20] also reported higher expansions on SF specimens in the $\mathrm{MgSO}_{4}$ solution.

Consistent with [4] elongation was observed to increase with immersion time.

TABLE IV: ELONGATION OF AHS REPLACED SPECIMENS IN THE SODIUM

\begin{tabular}{ccc}
\hline & SULFATE SOLUTION (MM) & \\
\hline \hline & Control & AHS \\
\hline Week 1 & 0.0208 & 0.0042 \\
\hline Week 2 & 0.0260 & 0.0208 \\
\hline Week 3 & 0.0302 & 0.0333 \\
\hline Week 4 & 0.0417 & 0.0333 \\
\hline Week 8 & 0.0042 & 0.0917 \\
\hline 4 months & 0.0692 & 0.2667 \\
\hline 8 months & 0.2583 & 0.3104 \\
\hline 9 months & 0.4854 & 0.7792 \\
\hline \hline
\end{tabular}

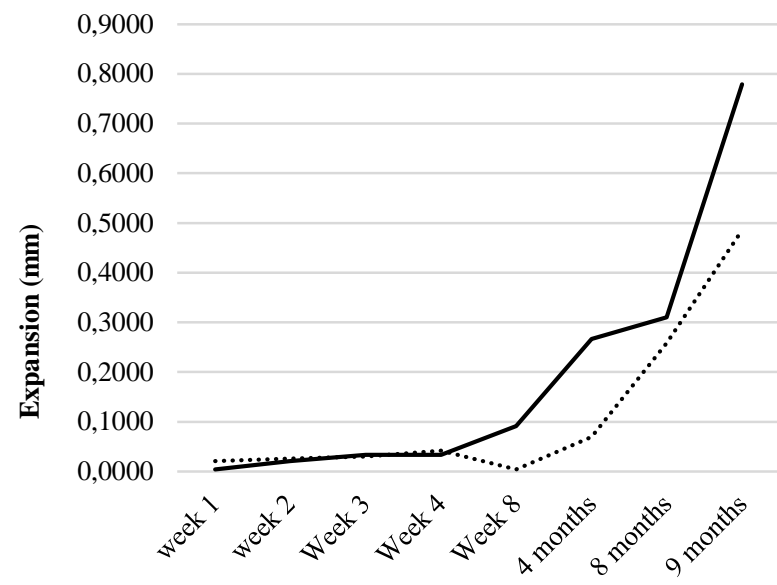

Time of exposure

$$
\text { …....... Control — AHS }
$$

Fig. 4. Elongation of AHS replaced specimens in the sodium sulfate solution against time $(\mathrm{mm})$

However, the expansions for all specimens in the $\mathrm{Na}_{2} \mathrm{SO}_{4}$ solution were higher than those of specimens immersed in the $\mathrm{MgSO}_{4}$ and mixed sulfate solutions, consistent with [4] who reported only a small change in length in the $\mathrm{MgSO}_{4}$ and the mixed sulfate solutions for all the specimens, compared with the $\mathrm{Na}_{2} \mathrm{SO}_{4}$ solution. Moon, et al. [4] attributed the expansion in the $\mathrm{MgSO}_{4}$ solution to the lower alkalinity that is associated with the formation of brucite in the cement matrix due to the presence of magnesium ions

TABLE V: ELONGATION OF AHS REPLACED SPECIMENS IN THE MAGNESIUM SULFATE SOLUTION (MM)

\begin{tabular}{ccc}
\hline \hline & Control & AHS \\
\hline Week 1 & 0.025 & 0.0167 \\
\hline Week 2 & 0.0027 & 0.0208 \\
\hline Week 3 & 0.0029 & 0.0042 \\
\hline Week 4 & 0.0042 & 0.0042 \\
\hline Week 8 & 0.075 & 0.0208 \\
\hline 4 months & 0.1833 & 0.0417 \\
\hline 8 months & 0.1854 & 0.05 \\
\hline 9 months & 0.1875 & 0.3125 \\
\hline \hline
\end{tabular}

Expansion of AHS specimens in MgSO4 solution against time (mm)

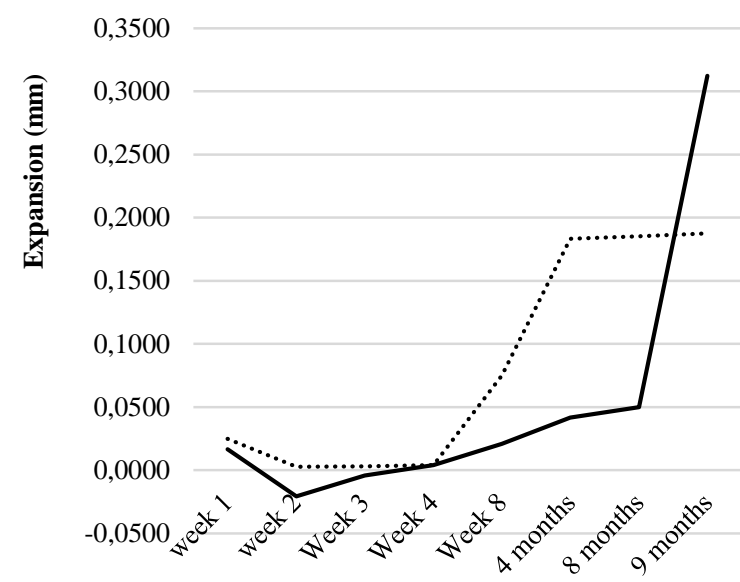

Time of exposure

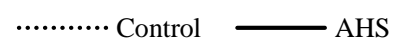

Fig. 5. Elongation of AHS replaced specimens in the $\mathrm{MgSO}_{4}$ solution against time (mm).

TABLE VI: ELONGATION OF AHS REPLACED SPECIMENS IN THE MIXED SOLUTION OF SODIUM AND MAGNESIUM

\begin{tabular}{ccc}
\hline \hline & Control & AHS \\
\hline Week 1 & 0.0052 & 0.0917 \\
\hline Week 2 & 0.0135 & 0.1292 \\
\hline Week 3 & 0.0177 & 0.1333 \\
\hline Week 4 & 0.0129 & 0.1469 \\
\hline Week 8 & 0.1417 & 0.2292 \\
\hline 4 months & 0.200 & 0.3000 \\
\hline 8 months & 0.1500 & 0.3333 \\
\hline 9 months & 0.3500 & 0.6042 \\
\hline \hline
\end{tabular}
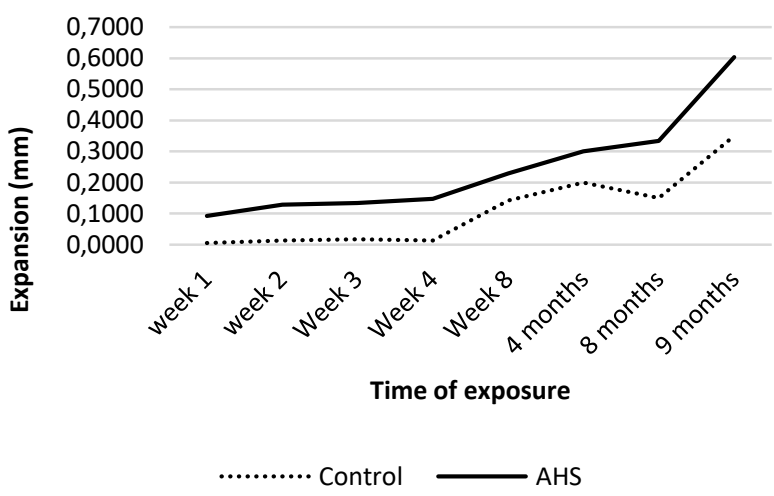

Fig. 6. Elongation of AHS replaced specimens in the mixed solution of $\mathrm{Na}_{2} \mathrm{SO}_{4}$ and $\mathrm{MgSO}_{4}$ against time (mm)

\section{Strength deterioration}

TABLE VII: STRENGTH DETERIORATION FACTOR (SDF) OF AHS SPECIMENS IN SODIUM, MAGNESIUM AND MIXED SULFATE SOLUTIONS

\begin{tabular}{cccc}
\hline \hline Specimens & $\mathrm{Na}_{2} \mathrm{SO}_{4}$ & $\mathrm{MgSO}_{4}$ & $\mathrm{Na}_{2} \mathrm{SO}_{4}+\mathrm{MgSO}_{4}$ \\
\hline Control & 8.6 & 17.7 & 26.9 \\
\hline AHS & 2.4 & 31.7 & 16.8 \\
\hline \hline
\end{tabular}




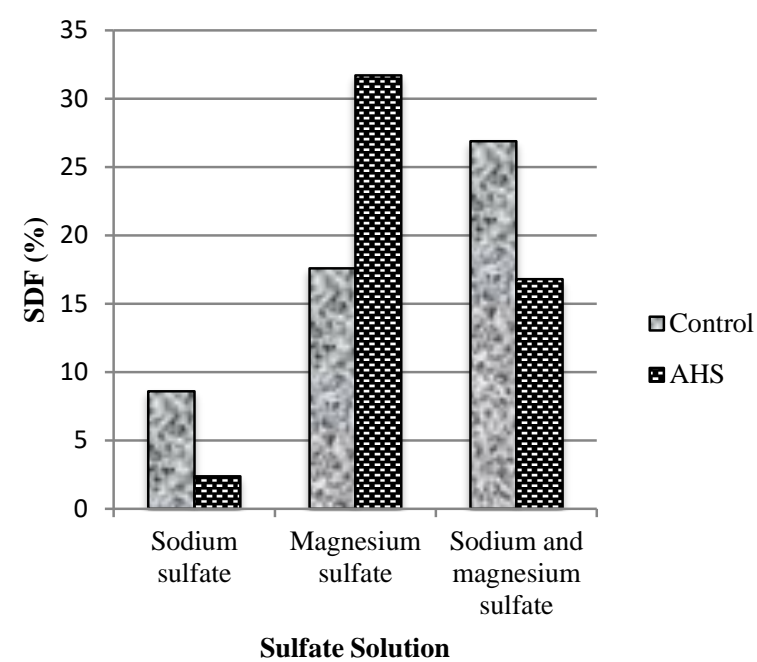

Fig. 7. Strength Deterioration Factor (SDF) of AHS specimens in $\mathrm{Na}_{2} \mathrm{SO}_{4}$, $\mathrm{MgSO}_{4}$ and mixed sulfate solutions

Table VII and Fig. 7 show the percentage Strength Deterioration Factors (SDFs) of specimens that were immersed in solutions of $\mathrm{Na}_{2} \mathrm{SO}_{4}, \mathrm{MgSO}_{4}$ and mixed $\mathrm{Na}_{2} \mathrm{SO}_{4}$ and $\mathrm{MgSO}_{4}$ solutions. The SDFs of AHS replaced specimens were 2.4, 31.7, and 16.8 while those of the control specimens were 8.6, 17.7, and 26.9 for the $\mathrm{Na}_{2} \mathrm{SO}_{4}$, $\mathrm{MgSO}_{4}$ and mixed $\mathrm{Na}_{2} \mathrm{SO}_{4}$ and $\mathrm{MgSO}_{4}$ solutions respectively.

The performances of AHS specimens were lower than those of the control specimens in the $\mathrm{MgSO}_{4}$ solution. These findings were consistent with literature that $\mathrm{MgSO}_{4}$ attack manifests itself through the loss of strength of concrete, and is more pronounced in pozzolanic concretes [2], [4], [7]. Also consistent with literature, it was found that the reaction between $\mathrm{Na}_{2} \mathrm{SO}_{4}$ and $\mathrm{C}-\mathrm{S}-\mathrm{H}$ is negligible; hence the manifestation and evaluation of $\mathrm{Na}_{2} \mathrm{SO}_{4}$ attack through expansion due to the presence of gypsum and ettringite [2], [4], [7].

The low levels of C-S-H in the control specimens was termed by [4] as the reason for the good performance of control specimens in the $\mathrm{MgSO}_{4}$ solution, since $\mathrm{MgSO}_{4}$ attack is controlled by magnesium attack on C-S-H. However, since SCMs contain less $\mathrm{Ca}(\mathrm{OH})_{2}$ and more C-S$\mathrm{H}, \mathrm{MgSO}_{4}$ readily reacts with the secondary C-S-H gel, decomposing it to the M-S-H gel, that in turn allows the easy diffusion of sulfate ions into the concrete matrix once the combined layer of gypsum and brucite has peeled off [2]. The good performance of the control specimens in the $\mathrm{MgSO}_{4}$ solution was attributed by [4] to the pore blocking effect by the formation of the less permeable brucite.

The results were also consistent with [4], who reported lower SDFs on SF-replaced specimens in the $\mathrm{Na}_{2} \mathrm{SO}_{4}$ solution compared with those of the control, whereas for specimens that were immersed in solutions that contained $\mathrm{MgSO}_{4}$, the SDF of SF-replaced specimens were higher than those of the control specimens. Lower SDFs than those of the control specimens were however recorded for the AHS specimens in the mixed sulfate solution, unlike in [4]'s work where higher SDFs were reported for SF-replaced specimens immersed in the mixed sulfate solution compared to those immersed in individual sulfate solutions of $\mathrm{Na}_{2} \mathrm{SO}_{4}$ and $\mathrm{MgSO}_{4}$.

From the SDF results, it can be concluded that AHS could be used in concrete with an advantage over $100 \%$ cement in $\mathrm{Na}_{2} \mathrm{SO}_{4}$ environments and environments of mixed $\mathrm{Na}_{2} \mathrm{SO}_{4}$ and $\mathrm{MgSO}_{4}$.

\section{Surface deterioration}

TABLE VIII: SURFACE DETERIORATION OF AHS SPECIMENS SUBJECTED TO SULFATE SOLUTIONS [21]

\begin{tabular}{lccc}
\hline \hline Specimen & $\mathrm{Na}_{2} \mathrm{SO}_{4}$ & $\mathrm{MgSO}_{4}$ & $\mathrm{Na}_{2} \mathrm{SO}_{4}+\mathrm{MgSO}_{4}$ \\
\hline Control & 0 & 0 & 2 \\
\hline AHS & 0 & 1 & 2 \\
\hline \hline
\end{tabular}

Key: Deterioration levels. 0, no damage; 1, minimum visible cracks; 2, mass loss and some disintegration; 3, extensive spalling and softening; 4, wider cracks and extensive spalling; 5, Complete disintegration

Table VIII shows the surface deterioration levels of AHS specimens immersed in $5 \% \mathrm{MgSO}_{4}, 5 \% \mathrm{Na}_{2} \mathrm{SO}_{4}$, and the mixed solution of $\mathrm{Na}_{2} \mathrm{SO}_{4}$ and $\mathrm{MgSO}_{4}$ based on [21].

Visual observations showed no damage on both the control and AHS specimens that were immersed in the $\mathrm{Na}_{2} \mathrm{SO}_{4}$ solution, minimum visible cracks were observed on the AHS specimens immersed in the $\mathrm{MgSO}_{4}$ solution, while mass loss and some disintegration was observed on both the control and AHS-replaced specimens that were immersed in the mixed solution of $\mathrm{Na}_{2} \mathrm{SO}_{4}$ and $\mathrm{MgSO}_{4}$. The results were consistent with literature that the predominance of the more aggressive $\mathrm{MgSO}_{4}$ attack over $\mathrm{Na}_{2} \mathrm{SO}_{4}$ attack is spelled in the mixed sulfate solution [4].

The presence of gypsum and bruicite confirmed by [4] from specimens that were immersed in the $\mathrm{MgSO}_{4}$ solution was considered by the authors as being the cause of deterioration to the surface of specimens.

\section{ACKNOWLEDGMENT}

The authors would like to acknowledge Agnes Muringo Mwangi and Samwel Kibiribiri for supplying anthill soil, Rebecca Chege and Tamia Chege for helping out in the laboratory, and Philomena Chege, for her patience.

\section{REFERENCES}

[1] D. Adesanya and A. Raheem, "A study of the permeability and acid attack of corn cob ash blended cements," Construction and Building Materials, vol. 24, pp. 403-409, 2010.

[2] J. D. Bapat, Mineral admixtures in cement and concrete: CRC Press, 2012.

[3] M. Shetty, Concrete technology: theory and practice: S. Chand. ISBN 8121900034, 2005.

[4] H.-Y. Moon, S.-T. Lee, and S.-S. Kim, "Sulphate resistance of silica fume blended mortars exposed to various sulphate solutions," Canadian Journal of Civil Engineering, vol. 30, pp. 625-636, 2003.

[5] M. Santhanam, M. D. Cohen, and J. Olek, "Mechanism of sulfate attack: a fresh look: Part 2. Proposed mechanisms," Cement and Concrete Research, vol. 33, pp. 341-346, 2003.

[6] H. Moon, S. Lee, and H. Kim, "The selection of effective Korean cement for sulfate environments," in Proceeding of the 3rd International Conference on Concrete Under Severe Conditions, CONSEC, 2001, pp. 349-356.

[7] F. Türker, F. Aköz, S. Koral, and N. Yüzer, "Effects of magnesium sulfate concentration on the sulfate resistance of mortars with and without silica fume," Cement and concrete research, vol. 27, pp. 205 214, 1997.

[8] A. S. Nene and Y. D. Parihar. (2016, 29.11.2016). Natural Stabilization of soils with special reference to Entomological Considerations.

Available: http://www.slideshare.net/ashoknene/natural-satbilization-of-soils

[9] J. Kamau, A. Ahmed, P. Hirst, and J. Kangwa, "Suitability of Anthil Soil as a supplementary cementitious material " 2017. 
[10] American Society for Testing and Materials, "ASTM C618. Standard specification for coal fly ash and raw or calcined naturalpozzolan for use in concrete, American Society for Testing and Materials, ASTM International, West Conshohocken, PA, 2012, DOI: 10.1520/C0618 $12, "$ ed, 2012.

[11] British Standards Institution, "BS EN 197-1:2000. Part 1. Cement composition, specifications and conformity criteria for common cements. British Standards Institution (BSI), London, UK," in BSOL, ed, 2000.

[12] British Standards Institution, "BS EN 1992-1-1:2000. Eurocode 2: Design of Concrete Structures, Part 1-1: General Rules and Rules for Buildings. BSI, London, UK," ed, 2004.

[13] C. Arya, Design of structural elements: concrete, steelwork, masonry and timber designs to British standards and Eurocodes. Spon Press, LONDON AND NEW YORK: Taylor \& Francis, 2009.

[14] C. L. Page and M. M. Page, Durability of concrete and cement composites: Elsevier, Woodhead publishing. ISBN 9781855739406, 2007.

[15] M. O. Mulwa, T. o. J. Karanja, and M. J. Wachira, "Effect of sulphate ions in mixing water on cement mortar performance. Chemistry Department, Kenyatta University, Kenya. School of Pure and Applied Sciences, Embu University College, Kenya.," IOSR Journal of Applied Chemistry (IOSR-JAC), vol. 9, pp. 11-15, 2016.

[16] American Society for Testing and Materials, "ASTM C1012/C1012M-15. Standard Test Method for Length Change of Hydraulic-Cement Mortars Exposed to a Sulfate Solution1. 100 Barr Harbor Drive, PO Box C700, West Conshohocken, PA 19428-2959. United States," ed, 2015.

[17] Understanding cement. (2016, 18.09.2016). Intepreting Cement Science Since 2005.Portland cement clinker: the Bogue calculation. Available: http://www.understanding-cement.com/bogue.html

[18] J. Tishmack, J. Olek, and S. Diamond, "Characterization of highcalcium fly ashes and their potential influence on ettringite formation in cementitious systems," Cement Concrete and Aggregates, vol. 21, pp. 82-92, 1999.

[19] G. Osborne, "Durability of Portland blast-furnace slag cemen concrete," Cement and Concrete Composites, vol. 21, pp. 11-21, 1999.
[20] Y.-S. Park, J.-K. Suh, J.-H. Lee, and Y.-S. Shin, "Strength deterioration of high strength concrete in sulfate environment," Cement and concrete research, vol. 29, pp. 1397-1402, 1999.

[21] O. S. B. Al-Amoudi, "Studies on soil-foundation interaction in the sabkha environment of eastern province of Saudi Arabia," Civil Engineering, 1992

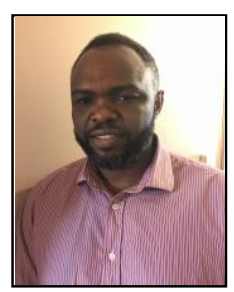

J. Kamau, the main author was born in Kenya. He graduated with a Bachelor of Science with honours degree in civil engineering from Leeds Becket University, Leeds, West Yorkshire, United Kingdom (UK) in 2010 and a Master of Science degree in structural engineering from the University of Leeds, Leeds, West Yorkshire, UK in 2011. He is currently undertaking a research programme on supplementary cementitious materials at the Leeds Beckett University, Leeds, West Yorkshire, UK.

He has worked in the past as a CIVIL ENGINEER and is currently working as a STRUCTURAL ENGINEER in Barnsley, South Yorkshire, UK. John already has several publications in the field of novel supplementay cement materials in concrete.

Mr. Kamau is a Graduate Member of the Institution of Civil Engineers (GMICE)

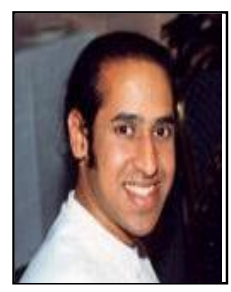

A. Ahmed, was born in Manchester, UK. He graduated with a Bachelor of Science with honors degree in Materials Science from Manchester University, United Kingdom (UK) and a Master of Philosophy degree in Metallurgy from the University of Manchester, UK. He then completed his $\mathrm{PhD}$ in Polymer Science from Heriot-Watt University, Edinburgh, UK.

He has been a Senior Lecturer at Leeds Beckett University since 2005, teaching modules in materials science at undergraduate and postgraduate levels. Previously Head of Civil Engineering, Dr Ahmed has several publications in the field of sustainable masonry and concrete materials. His area of research is in the field of sustainable construction materials using recycled and waste products. 